\title{
Effect of pH on growth and domoic acid production by potentially toxic diatoms of the genera Pseudo-nitzschia and Nitzschia
}

\author{
Nina Lundholm ${ }^{1, *}$, Per Juel Hansen ${ }^{1}$, Yuichi Kotaki ${ }^{2}$ \\ ${ }^{1}$ Marine Biological Laboratory, Strandpromenaden 5, 3000 Helsingør, Denmark \\ ${ }^{2}$ School of Fisheries Sciences, Kitasato University, Sanriku, Ofunato 022-0101, Japan
}

\begin{abstract}
The effect of elevated $\mathrm{pH}$ on growth and on production of the neurotoxin domoic acid was studied in selected diatoms belonging to the genera Pseudo-nitzschia and Nitzschia. Growth of most of the 11 species studied stopped at $\mathrm{pH}$ values of 8.7 to 9.1. However, for P. delicatissima and $N$. navis-varingica the $\mathrm{pH}$ limit for growth was higher, 9.3 and 9.7 to 9.8 , respectively. A compilation of all available data on the $\mathrm{pH}$ limits for growth of marine planktonic diatoms suggests that species from ponds and rock pools all have higher limits than coastal and oceanic species. Taking only coastal and oceanic species into account, the data suggest that smaller species have a higher upper $\mathrm{pH}$ limit for growth than larger species. Elevated $\mathrm{pH}$ induced production of domoic acid in P. multiseries in amounts comparable to those detected previously under silicate and phosphate limitation. As Pseudo-nitzschia species are found in high concentrations in nutrient-enriched areas, high $\mathrm{pH}$ and hence induction of the production of domoic acid would be expected during blooms. These results may help to understand when and why Pseudo-nitzschia species produce domoic acid in the field.
\end{abstract}

KEY WORDS: Cell volume $\cdot$ Diatom $\cdot$ Domoic acid $\cdot$ Growth rate $\cdot \mathrm{pH} \cdot$ Phytoplankton $\cdot$ Pseudonitzschia $\cdot$ Toxin production

\section{INTRODUCTION}

Diatoms are receiving increasing attention worldwide due to the ability of some species to produce the neurotoxic amino acid, domoic acid (Hasle 2002). At present, at least 9 different Pseudo-nitzschia species (P. australis, P. calliantha, P. delicatissima, P. fraudulenta, P. multiseries, P. multistriata, P. pseudodelicatissima, P. seriata and P. turgidula) and 1 Nitzschia species ( $N$. navis-varingica) have been reported to produce domoic acid (e.g. Bates 2000, Kotaki et al. 2000, Lundholm et al. 2003). Domoic acid (DA) may accumulate in the food web, and organisms such as mussels, scallops, clams, crabs, krill and planktonfeeding fishes may serve as vectors for the toxin (e.g. McGinness et al. 1995, Bargu et al. 2002). Domoic acid may thereby cause harm to seabirds, mammals and humans (e.g. Bates et al. 1989, Work et al. 1993,
Scholin et al. 2000, Gulland et al. 2002). Among gastrointestinal and neurological symptoms in humans, one of the distinct symptoms is amnesia; hence the use of the term 'amnesic shellfish poisoning (ASP)' for poisoning with DA.

Some research has been directed towards resolving which factors might influence toxin production. Laboratory experiments have shown that depletion of silicate, phosphate and iron enhance the production of DA (Bates et al. 1991, Pan et al. 1996a, b, C, Maldonado et al. 2002), whereas depletion of nitrogen in batch cultures results in a reduction in DA production (Bates et al. 1991). As for several other toxins, photosynthesis is required for production of DA (Pan et al. 1998) and periods of darkness result in cessation of toxin production (Bates et al. 1991). Experiments have shown that irradiance of $\geq 100 \mu \mathrm{mol}$ photons $\mathrm{m}^{-2} \mathrm{~s}^{-1}$ ensures that neither growth nor production of DA is limited (Bates 1998). 
Pseudo-nitzschia spp. blooms are often found in coastal areas enriched by nutrient-rich freshwater runoff (Smith et al. 1990, 1993, Horner \& Postel 1993, Dortch et al. 1997, Scholin et al. 2000, Odebrecht et al. 2001) or in upwelling areas (Abrantes \& Moita 1999, Trainer et al. 2000, Villac \& Tenenbaum 2001). A positive relationship between increasing eutrophication of coastal waters and the abundance of Pseudo-nitzschia spp. was found in present and historical data from the coast of Louisiana and Texas (Dortch et al. 1997, Parsons et al. 2002). Hence, nutrient enrichment may result in increased densities of phytoplankton organisms such as Pseudo-nitzschia spp.

In seawater, $\mathrm{pH}$ has generally been recognised as being very stable $(\mathrm{pH} \approx 8.2$ ), as it is buffered by the carbonate system. However, uptake of dissolved inorganic carbon (DIC) during photosynthesis by high densities of phytoplankton may actually cause an increase in $\mathrm{pH}$, and thus high $\mathrm{pH}$ values (around $\mathrm{pH}$ 9) have been recorded in natural environments during algal blooms (Hinga 1992, 2002, Macedo et al. 2001). For instance, in Narrangansett Bay, USA, $18 \%$ of the samples had $\mathrm{pH}$ values above 8.7 (Hinga 2002). Similarly, during the development of a bloom of the haptophyte Phaeocystis spp. in the North Sea, Brussard et al. (1996) found an increase in $\mathrm{pH}$ from 7.9 to 8.7. In fjords and coastal lagoons, $\mathrm{pH}$ values can attain even higher levels, and $\mathrm{pH}$ values up to around 10 may then be found during bloom periods (e.g. Marshall \& Orr 1948, Macedo et al. 2001, Hansen 2002). The only study that we have been able to find in which $\mathrm{pH}$, growth of potentially toxic diatoms and DA content has been studied is that of Douglas et al. (1993). However, the scope of that study was confined to comparing production of DA in non-axenic and axenic strains, and it was not possible to conclude what caused the growth limitation recorded in that study; as indicated by the authors, no conclusions could be made about the effect of $\mathrm{pH}$ on growth or on DA cell content and production.

As Pseudo-nitzschia spp. comprise bloom-forming species that are often found in nutrient-enriched areas, and as $\mathrm{pH}$ is expected to increase during algal blooms, we found it appropriate to conduct a study on the effect of $\mathrm{pH}$ on growth and toxin production of potentially toxic strains of Pseudo-nitzschia. Thus, the aim of the present study was to examine the effect of elevated $\mathrm{pH}$ on growth and toxin production of different potentially toxic diatoms in batch culture supplied with a surplus of nutrients. We also investigated the $\mathrm{pH}$ limits for growth of different strains of Pseudo-nitzschia and of a single Nitzschia species ( $N$. navis-varingica) isolated from environments of different levels of trophy (oligotrophy-hypertrophy) to evaluate their tolerance to high $\mathrm{pH}$.

\section{MATERIALS AND METHODS}

Algae species, clones and culture conditions. Different strains of Pseudo-nitzschia and Nitzschia were used. Information on strain designation, isolation place and date, and on the donors of the strains is given in Table 1. All strains were clonal and non-axenic and grown in L1-medium (Guillard \& Hargraves 1993) based on autoclaved seawater with a salinity of $32 \mathrm{psu}$. Extra silicate was added to achieve a concentration $(321 \mu \mathrm{M}) 3$ times higher than originally described for the L1-medium. The stock cultures were maintained at $15 \pm 1^{\circ} \mathrm{C}$ and 15 to $25 \mu \mathrm{mol}$ photons $\mathrm{m}^{-2} \mathrm{~s}^{-1}$ following a light:dark cycle of 16:8 h. Illumination was provided by cool fluorescent lamps and irradiance was measured using a Li-1000, Li-Cor sensor equipped with a Li193SA spherical quantum probe.

Calculations of cell volumes were based on measurements on 10 to 20 cells of each strain, picked in exponential growth phase. Cell volumes were calculated according to Hillebrand et al. (1999) but with modifications for Pseudo-nitzschia spp. It was assumed that the linear part of Pseudo-nitzschia cells accounts for $60 \%$ of the cell length; hence this part of the cell volume was calculated as a rectangular box. Calculation of the remaining part of the cell volume was based on a prism on a parallelogram-base at each end. An additional assumption was that the width and height of Pseudonitzschia cells were similar. Thus the cell volume of Pseudo-nitzschia spp. was calculated using the equation:

$$
\text { Volume }=\left(0.6 \times L \times W^{2}\right)+\left(0.4 \times 0.5 \times L \times W^{2}\right)
$$

where $L$ is the cell length and $W$ is the width of the cell.

General experimental conditions. The experiments were carried out at an irradiance of $100 \mu \mathrm{mol}$ photons $\mathrm{m}^{-2} \mathrm{~s}^{-1}$ to ensure that neither growth nor production of DA was light-limited (Bates 1998). Otherwise conditions were as described above. Prior to all experiments, the strains were acclimated to the experimental conditions for at least $7 \mathrm{~d}$. Inoculates used for the experiments were taken from exponentially growing cultures. Initial experimental concentrations were 2000 cells $\mathrm{ml}^{-1}$, and all experiments were carried out in triplicate flasks containing the volumes given below.

The medium used for the experiments was adjusted to the experimental $\mathrm{pH}$ by addition of $1 \mathrm{mM} \mathrm{HCl}$ or $\mathrm{NaOH}$. pH was measured using a Sentron $\mathrm{pH}$ meter (Model ArgusX) equipped with a red line probe with a relative accuracy of $\pm 0.01 \%$. The $\mathrm{pH}$ meter was calibrated (2-point calibration) using Sentron buffers of pH 7 and 10 .

Subsamples for cell counting $(5 \mathrm{ml})$ and toxin analyses $(2 \times 10 \mathrm{ml})$ were taken at approximately the same time every day, and the $\mathrm{pH}$ of the medium was mea- 
Table 1. Pseudo-nitzschia spp. and Nitzschia spp. Information on strain designations, sampling locations and times, and donors

\begin{tabular}{|c|c|c|c|}
\hline Strain & Species & Sampling location and date & Donor \\
\hline CL-193 & P. pungens & $\begin{array}{l}\text { Deadmans Harbour, Bay of Fundy, Canada, } \\
\text { Oct 9, } 2002\end{array}$ & S. Bates \\
\hline CL-195 & P. multiseries & $\begin{array}{l}\text { Deadmans Harbour, Bay of Fundy, Canada, } \\
\text { Oct 9,2002 }\end{array}$ & S. Bates \\
\hline OKPm013-2 & P. multiseries & $\begin{array}{l}\text { Okkiray Bay, Iwate Prefecture, Japan, } \\
\text { Sep 20, } 2001\end{array}$ & Y. Kotaki \\
\hline VHL987 & N. navis-varingica & $\begin{array}{l}\text { Ha Long Bay, Vietnam, } \\
\text { Dec 5, } 1998\end{array}$ & Y. Kotaki \\
\hline PS111V & P. australis & $\begin{array}{l}\text { Baiona, Ría de Vigo, Spain, } \\
\text { Sep 20, } 2001\end{array}$ & S. Fraga \\
\hline NWFSC095 & Pseudo-nitzschia sp. & $\begin{array}{l}\text { Sequim Bay, Washington, USA, } \\
\text { Aug } 8,2002\end{array}$ & B. Bill \\
\hline CL-190 & P. calliantha & $\begin{array}{l}\text { Baie- Sainte-Anne, New Brunswick, Canada, } \\
\text { Sep 30, } 2002\end{array}$ & S. Bates \\
\hline Tasm10 & P. delicatissima & $\begin{array}{l}\text { Hobart Harbour, Tasmania, } \\
\text { Feb } 13,2000\end{array}$ & N. Lundholm \\
\hline CL-192 & P. fraudulenta & $\begin{array}{l}\text { Deadman's Harbour, Bay of Fundy, Canada, } \\
\text { Oct 9, } 2002\end{array}$ & S. Bates \\
\hline PG & P. granii & $\begin{array}{l}\text { Ocean Station Papa, NE Pacific (latitude } 50.0^{\circ} \mathrm{N} \text {, } \\
\text { longitude } 145.0^{\circ} \mathrm{W} \text { ), Jun } 2000\end{array}$ & R. El Sabaawii \\
\hline CL-159 & P. seriata & $\begin{array}{l}\text { Tracadie Harbour, Prince Edward Island, Canada, } \\
\text { Apr 9, } 2002\end{array}$ & S. Bates \\
\hline PT & P. cf. turgidula & $\begin{array}{l}\text { Ocean Station Papa, NE Pacific (latitude } 50.0^{\circ} \mathrm{N} \text {, } \\
\text { longitude } 145.0^{\circ} \mathrm{W} \text { ), Aug } 2002\end{array}$ & A. Marchetti \\
\hline
\end{tabular}

sured. After subsampling, the flasks were refilled with L1 medium of the same $\mathrm{pH}( \pm 0.05)$. Samples for enumeration were fixed in Lugol's solution (final concentration $2 \%$ ) and counted in a Sedgewick rafter chamber. Counts were based on approximately 400 cells, corresponding to a deviation of $\pm 10 \%$, using $95 \%$ confidence limits (Utermöhl 1958). Maximum growth rates $(\mu)$ were calculated using the algorithm:

$$
\mu=\ln \left(N_{t_{2}} / N_{t_{1}}\right) /\left(t_{2}-t_{1}\right)
$$

where $N_{t_{2}}$ and $N_{t_{1}}$ are cell numbers at times $t_{2}$ and $t_{1}$. We used 3 successive cell counts in the calculations. Dilutions due to subsampling were adjusted for in the calculations of the growth rates.

Subsamples (50 ml) for determination of $\mathrm{NH}_{4}{ }^{+}, \mathrm{NO}_{3}{ }^{-}$, $\mathrm{NO}_{2}^{-}, \mathrm{PO}_{4}{ }^{3-}$ and $\mathrm{SiO}_{4}{ }^{-}$were taken from the medium used for inoculation at the beginning (Day 0) and at the end (Day 29) of the experiment with Pseudo-nitzschia multiseries (Strain CL-195). For silicate analyses, $50 \mathrm{ml}$ were passed through a $5.0 \mu \mathrm{m}$ polycarbonate filter and the filtrate was frozen immediately. For analyses of $\mathrm{N}$ and $\mathrm{P}, 50 \mathrm{ml}$ of each nutrient was filtered through a $\mathrm{GF} / \mathrm{C}$ filter and the filtrate was frozen. The nutrients were determined according to the method of Valderrama (1995) using a Beckman DU 640 spectrophotometer. Simultaneously, samples for measurements of dissolved inorganic carbon content were taken and measured immediately using a $225 \mathrm{MK} 3$ infrared gas analyser (IRGA, ADC, Hoddesdon). We carried out 3 different experiments (Expts 1 to 3 ) to study the effects of elevated $\mathrm{pH}$ on the growth and DA production in selected potentially toxic diatom species.

Expt 1: Effect of pH on growth and DA production in pH-drift experiments. We grew 2 Pseudo-nitzschia multiseries strains (CL-195 and OKPm013-2) as batch cultures in $260 \mathrm{ml}$ Nunclon polystyrene flasks (260 ml medium) mounted on a plankton wheel (1 rpm) in order to keep the cells in suspension. The $\mathrm{pH}$ was adjusted to 8.0 prior to the experiment and afterwards allowed to drift. Cell concentration and $\mathrm{pH}$ were measured daily until stationary growth phase, and thereafter less frequently (1 to $4 \mathrm{~d}$ intervals). Samples for DA concentration in the whole culture and in the filtrate were taken 7 to 10 times during the duration of the experiments (30 d). Samples for nutrient and dissolved inorganic carbon analyses were taken prior to and at the end of the experiment for Strain CL-195.

Expt 2: Effect of different initial pH levels on growth and culture cell yield. In order to demonstrate that elevated $\mathrm{pH}$ and not depletion of vitamins, microor macronutrients were inhibiting growth, Pseudonitzschia multiseries Strain OKPm013-2 was grown in batch culture in $260 \mathrm{ml}$ Nunclon polystyrene flasks (260 ml medium) mounted on a plankton wheel 
(1 rpm). The $\mathrm{pH}$ was adjusted to 4 different initial values $(7.9,8.3,8.6$ and 8.8$)$ prior to the experiment, and subsequently pH was allowed to drift. Cell concentration and $\mathrm{pH}$ were followed daily until stationary growth phase, and thereafter less frequently (2 to $3 \mathrm{~d}$ intervals).

Expt 3: Role of environment and cell volume in $\mathbf{p H}$ tolerance of potentially toxic diatoms. The effect of elevated $\mathrm{pH}$ on the growth of 10 Pseudo-nitzschia species and Nitzschia navis-varingica (Table 1), isolated from temperate-subtropical areas with different nutri- ent levels, were studied in pH-drift experiments. All species were grown as previously described with the exception of $P$. seriata (Strain CL-159), a cold-water species which was grown in $62 \mathrm{ml}$ Nunclon flasks at $4^{\circ} \mathrm{C}$ and an irradiance of $55 \mu \mathrm{mol}$ photons $\mathrm{m}^{-2} \mathrm{~s}^{-1}$. In all experiments, the $\mathrm{pH}$ was adjusted to ca. 8.0 before the experiment and afterwards allowed to drift. Cell concentration and $\mathrm{pH}$ were followed daily until stationary growth phase, and thereafter less frequently (1 to $3 \mathrm{~d}$ intervals). Samples for DA concentration in the whole culture and in the filtrate were taken 6 times during
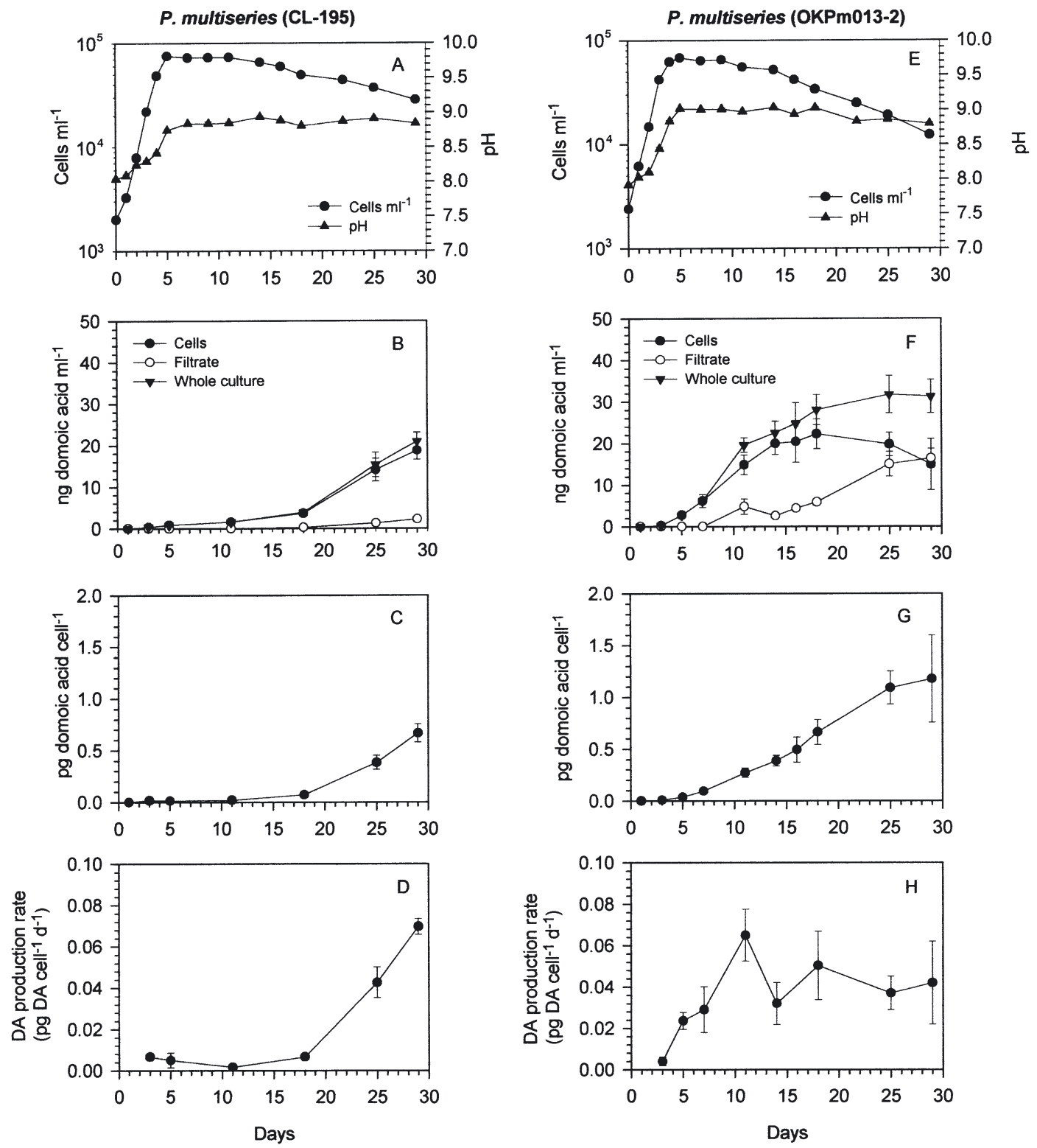

Fig. 1. Pseudo-nitzschia multiseries. Growth and toxin production of 2 strains: (A-D) Strain CL-195; (E-H) Strain OKPm013-2. $(\mathrm{A}, \mathrm{E})$ Cell concentration and $\mathrm{pH}$ as a function of time; $(\mathrm{B}, \mathrm{F})$ domoic acid content in cell fraction, medium and in whole culture as a function of time; $(C, G)$ content of DA per cell as a function of time; $(D, H)$ domoic acid production rate as a function of time. Data points are means $\pm \mathrm{SE}, \mathrm{n}=3$ (where SE bars are not visible, SE values were smaller than symbols) 
the duration $(30 \mathrm{~d})$ of the experiment with $P$. pungens (Strain CL-193).

Toxin analyses. At each subsampling, 2 samples of $10 \mathrm{ml}$ were taken. One was immediately frozen and used for determination of toxin content in the whole culture (cells plus medium), the other was filtered using a Nuclepore filter $(0.8 \mu \mathrm{m}$ pore size, $25 \mathrm{~mm}$ diameter) and the $8 \mathrm{ml}$ filtrate was stored at $-20^{\circ} \mathrm{C}$. After each experiment, the frozen samples were immediately sent for toxin analyses.

The whole-culture sample was thawed, sonicated under cool conditions $\left(<10^{\circ} \mathrm{C}\right)$ and centrifuged $(8000 \times g, 10 \mathrm{~min})$. The supernatant and the filtrate were analysed for DA concentration using a slightly modified method of Pocklington et al. (1990) in which an ODS-5 column $(4.6 \times 250 \mathrm{~mm}$, Nomura Chemical $)$ and a mobile phase of $40 \%$ acetonitrile in phosphate buffer ( $\mathrm{pH}$ 2.5) were used. The detection limit was $0.3 \mathrm{ng} \mathrm{ml}^{-1}$.

Toxin content in the cellular fraction was calculated by subtracting DA in the filtrate from that in the whole culture. The toxin content per cell was calculated by dividing the DA in the cellular fraction by the cell number. The DA production rate was calculated using the formula:

$$
\begin{aligned}
& \text { DA production rate }\left(\mathrm{pg} \mathrm{DA} \text { cell }^{-1} \mathrm{~d}^{-1}\right)= \\
& \frac{\mathrm{DA}_{2}-\mathrm{DA}_{1}}{0.5\left(N_{1}+N\right)\left(t_{2}-t_{1}\right)}
\end{aligned}
$$

where $\mathrm{DA}_{\mathrm{n}}$ is the domoic acid concentration (pg DA $\mathrm{ml}^{-1}$ in the whole culture), $N$ is cell concentration (cells ml-1) and $t$ is time (d) (modified from Pan et al. 2001). Dilutions through subsampling were adjusted for in the calculation of the DA production rate. According to Pan et al. (2001), breakdown of DA can be ignored.

\section{RESULTS}

\section{Effect of $\mathbf{p H}$ on growth and DA production in pH-drift experiments (Expt 1)}

For the first $5 \mathrm{~d}, 2$ Pseudo-nitzschia multiseries strains (CL-195 and OKPm013-2) grew exponentially with growth rates of $\sim 1 \mathrm{~d}^{-1}$. During this period, $\mathrm{pH}$ values increased from 8.0 to 8.5 (Fig. 1A,E, Table 2). After $5 \mathrm{~d}$, cells entered the stationary phase and $\mathrm{pH}$ stabilised at a maximum $\mathrm{pH}$ value (Fig. 1A,E). $\mathrm{pH}$ values at which no positive growth took place $(\mu=0)$ were between 8.8 and 9.0 (Table 2). The values of $\mathrm{pH}$ at which maximum growth rates were reduced by more than $20 \%$ were above 8.5 to 8.6 . The concentrations of the inorganic nutrients $(\mathrm{N}, \mathrm{P}, \mathrm{Si})$ were measured in the experiment with P. multiseries (Strain CL-195), and the results showed that the nutrients were in excess both at the beginning and at the end of the experiment (Table 3). A calculation of the estimated total uptake of inorganic nutrients by the cells using the maximum cell yield and the cellular content of N, P and Si supports this conclusion (Table 3).

Domoic acid was detected during the experiments with the 2 Pseudo-nitzschia multiseries strains CL-195 and OKPm013-2 (Fig. 1B,F). At the beginning of the experiment, on Day 1, no DA was detected (Fig. 1B,F), while low toxin concentrations in the whole culture were detected in the exponential growth phase (Day 3). At the end of exponential growth phase (Day 5 ; Fig. 1B,F) toxin concentrations (whole culture) had increased and continued doing so even after many days in the stationary phase.

The toxin was found in the filtrate during the stationary growth phase in all cultures (Days 11 to 18). During the remainder of the experiments, the toxin concentra-

Table 2. Pseudo-nitzschia spp. and Nitzschia navis-varingica. Maximum growth rates, cell volumes and pH limits for exponential growth for several strains. Environment: data from Hasle (1965, 2002), Kaczmarska et al. (1986), Hasle \& Syvertsen (1997), Kotaki et al. (2000), and Lundholm et al. (2003); Max. pH: maximum $\mathrm{pH}$ when growth rate $\mu=0$. nd: no data

\begin{tabular}{|llccc|}
\hline Species (Strain) & Environment & $\begin{array}{c}\text { Cell volume } \\
\left(\mu \mathrm{m}^{3} \pm \mathrm{SE}\right)\end{array}$ & $\begin{array}{c}\text { Max. specific growth } \\
\text { rate }\left(\mathrm{d}^{-1} \pm \mathrm{SE}\right)\end{array}$ \\
\hline N. navis-varingica (VHL987) & Marine ponds & $5427 \pm 196$ & $0.51 \pm 0.02$ & $9.7-9.8$ \\
P. delicatissima (Tasm 10) & Coastal + oceanic & $128 \pm 13$ & $1.47 \pm 0.01$ & 9.3 \\
P. australis (PS) & Coastal + oceanic? & $1307 \pm 73$ & $0.77 \pm 0.05$ & 8.9 \\
Pseudo-nitzschia sp. (NWFSC095) & Coastal + oceanic? & $306 \pm 25$ & $1.12 \pm 0.05$ & 8.9 \\
P. calliantha (CL-190) & Coastal + oceanic? & $250 \pm 12$ & $0.74 \pm 0.02$ & 9.0 \\
P. fraudulenta (CL-192) & Coastal + oceanic & $1536 \pm 103$ & $1.07 \pm 0.02$ & 8.8 \\
P. multiseries (CL-195) & Coastal + oceanic? & nd & $1.01 \pm 0.02$ & $8.8-8.9$ \\
P. multiseries (OKPm013-2) & Coastal + oceanic? & $1122 \pm 60$ & $1.01 \pm 0.05$ & 9.0 \\
P. pungens (CL-193) & Coastal + oceanic & nd & $1.14 \pm 0.04$ & $8.8-8.9$ \\
P. seriata (CL-159) & Coastal + oceanic & $1105 \pm 50$ & $0.65 \pm 0.03$ & 9.0 \\
P. granii (PG) & Mainly oceanic & $425 \pm 5$ & $1.81 \pm 0.05$ & 9.1 \\
P. cf. turgidula (PT) & Mainly oceanic & $479 \pm 73$ & $0.90 \pm 0.02$ & 8.7 \\
\hline
\end{tabular}


Table 3. Pseudo-nitzschia multiseries (Strain CL-195). Contents of inorganic N, P, Si and C in L1-medium at inoculation (Day 0) and in filtrate of batch cultures at end (Day 29) of experiment. Bottom of table shows calculations of total N, P, Si and C uptake using maximal cell concentrations in experiment with Strain CL-195. Total N, P, Si and C uptake calculated on the basis of cellular contents measured in P. multiseries by Pan et al. (1996c) in an experiment without nutrient limitation (Si: 43.78 pg cell ${ }^{-1}$, $\mathrm{N}: 11.23 \mathrm{pg} \mathrm{cell}^{-1}, \mathrm{P}: 1.65 \mathrm{pg} \mathrm{cell}^{-1} ; \mathrm{C}: 94.99 \mathrm{pg} \mathrm{cell}^{-1}$ )

\begin{tabular}{|c|c|c|c|c|c|c|}
\hline Sample & $\mathrm{NH}_{4}{ }^{+}(\mu \mathrm{M})$ & $\mathrm{NO}_{2}^{-}(\mu \mathrm{M})$ & $\mathrm{NO}_{3}^{-}(\mu \mathrm{M})$ & $\mathrm{PO}_{4}{ }^{3-}(\mu \mathrm{M})$ & $\mathrm{SiO}_{4}^{-}(\mu \mathrm{M})$ & $\mathrm{C}(\mathrm{mM})$ \\
\hline Day 0 & $0.23 \pm 0.01$ & $1.49 \pm 0.02$ & $1111.4 \pm 12.8$ & $47.0 \pm 0.2$ & $430.7 \pm 3.5$ & 1.9 \\
\hline \multirow[t]{3}{*}{ Day 29} & $0.43 \pm 0.04$ & $9.69 \pm 0.20$ & $1042.1 \pm 5.1$ & $39.0 \pm 0.2$ & $356.2 \pm 0.2$ & $1.73 \pm 0.03$ \\
\hline & \multirow{2}{*}{\multicolumn{2}{|c|}{$\begin{array}{l}\text { Max. cell conc. } \\
\quad\left(\text { cells } \mathrm{ml}^{-1}\right)\end{array}$}} & \multirow{2}{*}{\multicolumn{4}{|c|}{$\begin{array}{l}\text { - Estimated total uptake }(\mu \mathrm{m}) \text { of: } \\
\mathrm{PO}_{4}{ }^{3-} \\
\mathrm{SiO}_{4}^{-}\end{array}$}} \\
\hline & & & & & & \\
\hline CL-195 & \multicolumn{2}{|c|}{75000} & 60 & 4 & 117 & 593 \\
\hline
\end{tabular}

tion in the filtrate continued to increase (Fig. 1B,F). The amount of toxin in the cellular fraction increased from the exponential growth phase and continued to do so in the stationary phase.

The cellular toxin content (pg DA cell-1) increased throughout the experiment in Strain CL-195, whereas it seemed to reach a plateau in the late stationary phase in Strain OKPm013-2 (Fig. 1C,G). The production rates of DA, which represent the amount of DA produced between 2 sampling dates, were initially (exponential growth phase, Days 1 to 3 ) slightly positive (Fig. 1D,H). For Strain CL-195, this coincided with a slight increase in the amount of DA in the cells (Fig. 1D). The time course of DA production differed between the 2 strains. In Strain CL-195, the DA production rate increased during the stationary phase, especially during the latter part (Fig. 1D). In contrast, in Strain OKPm013-2 the DA production rate increased as early as the end of the exponential growth phase, and further increased at the beginning of the stationary phase; later in the stationary growth phase it decreased slightly and seemed to stabilise (Fig. 1H). Both strains reached maximum DA production rates of 0.07 pg DA cell ${ }^{-1} \mathrm{~d}^{-1}$.

\section{Effect of different initial pH levels on growth and culture cell yield (Expt 2)}

Pseudo-nitzschia multiseries (Strain OKPm013-2) inoculated at different initial $\mathrm{pH}$ levels showed exponential growth for the first 2 or $3 \mathrm{~d}$ in the flasks inoculated at the 3 lowest $\mathrm{pH}$ values (Fig. 2A). The flasks initiated at $\mathrm{pH} 8.8$ showed a lag phase of $1 \mathrm{~d}$ before the cultures started to grow exponentially. In all flasks, cultures entered stationary growth phase when $\mathrm{pH}$ reached 8.9 to 9.0. Hence, a negative linear relationship was found between maximum cell yield and $\mathrm{pH}$; a higher initial $\mathrm{pH}$ resulted in a lower maximum cell yield (Fig. 2C). For initial pH values of 7.9 to 8.6 , the stationary phase was reached at Days 4 to 5 . The flask that had an initial $\mathrm{pH}$ value of 8.8 experienced a slower growth rate and reached the stationary phase later.

The maximum growth rates at the different $\mathrm{pH}$ levels were not statistically different at $\mathrm{pH}$ values of 8.0 and
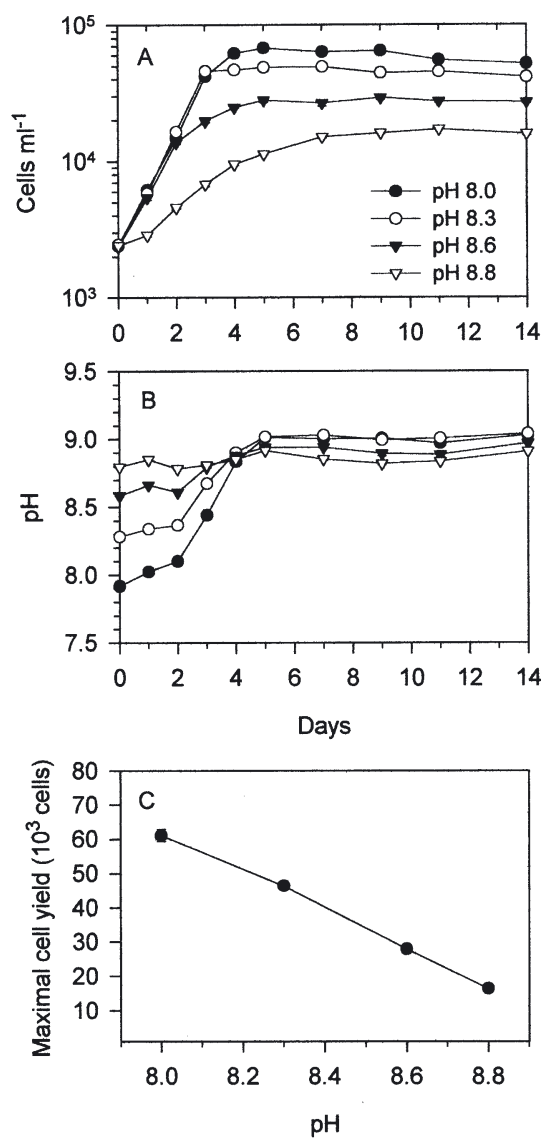

Fig. 2. Pseudo-nitzschia multiseries. Strain OKPm013-2 grown at different initial $\mathrm{pH}$ levels. (A) Changes in cell concentration as a function of time from inoculation at 4 different initial $\mathrm{pH}$ levels; (B) changes in $\mathrm{pH}$ as a function of time; (C) maximum cell yield in stationary phase as a function of time. Data points are means $\pm \mathrm{SE}, \mathrm{n}=3$ (where SE bars are not visible, SE values were smaller than symbols) 


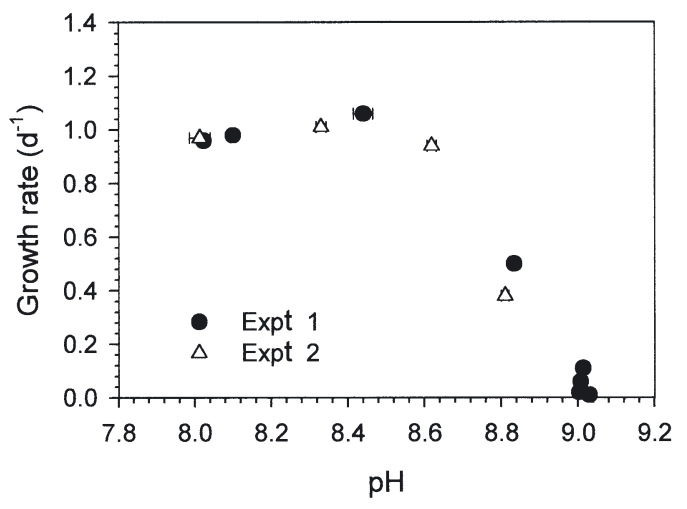

Fig. 3. Pseudo-nitzschia multiseries. Growth rate of Strain OKPm013-2 as a function of $\mathrm{pH}$. (•) Data from $\mathrm{pH}$ drift experiments with initial $\mathrm{pH}$ of 8 (Expt 1$)_{i}(\Delta)$ data from experiments with different initial $\mathrm{pH}$ levels (Expt 2). Data points are means $\pm \mathrm{SE}, \mathrm{n}=3$

8.3, with a maximum of $1.02 \mathrm{~d}^{-1}$ at $\mathrm{pH} 8.3$ (Student's $t$ test: $\mathrm{p}>0.05)$, and slightly lower at $\mathrm{pH} 8.6(t$-test: $\mathrm{p}<$ 0.05) (Fig. 3). Above pH 8.6, a dramatic decrease in maximum growth rates was found and a maximum growth rate of $0.38 \mathrm{~d}^{-1}$ was attained in the flask inoculated at $\mathrm{pH} 8.8$ ( $t$-test: $\mathrm{p}<0.001)$. Similar results could be obtained from the pH-drift experiments with Pseudo-nitzschia multiseries (Fig. 1E), using average values of $\mathrm{pH}$ and corresponding growth rates extracted day-by-day throughout the experiment. Combining both data sets, it is evident that growth rates were not affected significantly by pH below 8.6 (Fig. 3). When $\mathrm{pH}$ exceeded 8.6, the growth rate decreased until $\mathrm{pH}$ 9.0, above which no further positive growth was observed (Fig. 3).

\section{Role of environment and cell volume in $\mathrm{pH}$ tolerance of potentially toxic diatoms (Expt 3)}

The exponential growth phase occurred immediately or after a short lag-phase in all strains (Fig. 4). Maximum growth rates are shown in Table 2. The beginning of the stationary growth phase corresponded to the stabilisation of the $\mathrm{pH}$ values at a certain $\mathrm{pH}$ maximum (Fig. 4). The $\mathrm{pH}$ maximum, after which no further positive growth took place, varied among strains (Table 2). The large majority of species and clones had a pH limit for growth around 8.8 to 9.1. However, some exceptions were found. The highest $\mathrm{pH}$ limits for growth were reached by a strain of Nitzschia navis-varingica (9.7 to 9.8) isolated from a shrimp pond, and a coastal strain of Pseudo-nitzschia delicatissima (9.3). The oceanic P. cf. turgidula had the lowest $\mathrm{pH}$ limit for growth (8.7), whereas the other oceanic strain, P. granii, had a higher maximum $\mathrm{pH}$ (9.1).
Data on $\mathrm{pH}$ limits for growth and cell volume of planktonic diatoms were collected from the literature and combined with our own data. This gave a significant semi-logarithmic relationship (linear regression: $\mathrm{p}<0.001$ and $\mathrm{r}^{2}=0.54$ ) between the upper $\mathrm{pH}$ limit and the cell volumes of the diatoms (Fig. 5), which can be described by the equation:

$$
\mathrm{pH}=9.76-0.281 \times \log \text { cell volume }\left(\mu^{3}\right)
$$

Thus, small diatoms have a higher upper $\mathrm{pH}$ limit for growth than large diatoms. No DA was detected in any of the subsamples of Pseudo-nitzschia pungens collected throughout the experiment.

\section{DISCUSSION}

\section{Effect of high pH on growth of Pseudo-nitzschia spp.}

It was our intent to study how $\mathrm{pH}$ affected both growth and toxin production in DA-producing diatoms. Thus, we had to ensure that other factors such as macronutrients, micronutrients, vitamins and light were not limiting algal growth in our study. Irradiance was provided at an intensity that satisfies both growth and the photosynthetic energy requirement for production of DA by Pseudo-nitzschia multiseries (Bates 1998). We could directly demonstrate that nitrate, phosphate, silicate and total dissolved inorganic carbon were available in non-limiting concentrations both before and after the experiments (Table 3). The concentrations found are clearly above the concentrations previously reported to limit growth of $P$. multiseries and correspond to or exceed concentrations used in non-nutrient limiting experiments (Bates et al. 1993, Pan et al. 1996a,b,c). Nutrient excess in the present study is also indicated when comparing the total amount of nutrient uptake with the amount left at the end of the experiment (Table 3). To ensure that micronutrients and vitamins were not limiting growth, we ran an experiment in which $P$. multiseries (Strain OKPm013-2) was grown at different initial $\mathrm{pH}$ levels. In this experiment, it was evident that whenever $\mathrm{pH}$ reached values of about 8.9 to 9.0 growth stopped, independent of the cell concentration, and therefore independent of the concentration of macro- and micronutrients and vitamins. Hence, an inverse linear relationship was observed between initial pHs and maximum cell yield (Fig. 2C). Thus, our results of nutrient measurements as well as the experiment with different initial $\mathrm{pH}$ demonstrate that neither micro- or macronutrients nor vitamins were limiting growth of $P$. multiseries, and that $\mathrm{pH}$ was the limiting factor. These results support previous findings of $\mathrm{pH}$ as a limiting factor for growth of other microalgae grown in 
nutrient-rich media such as f/2 growth medium (e.g. Schmidt \& Hansen 2001, Hansen 2002, Hinga 2002).

Although positive growth of Pseudo-nitzschia multiseries continued until the $\mathrm{pH}$ reached 8.9 to 9.0 , the
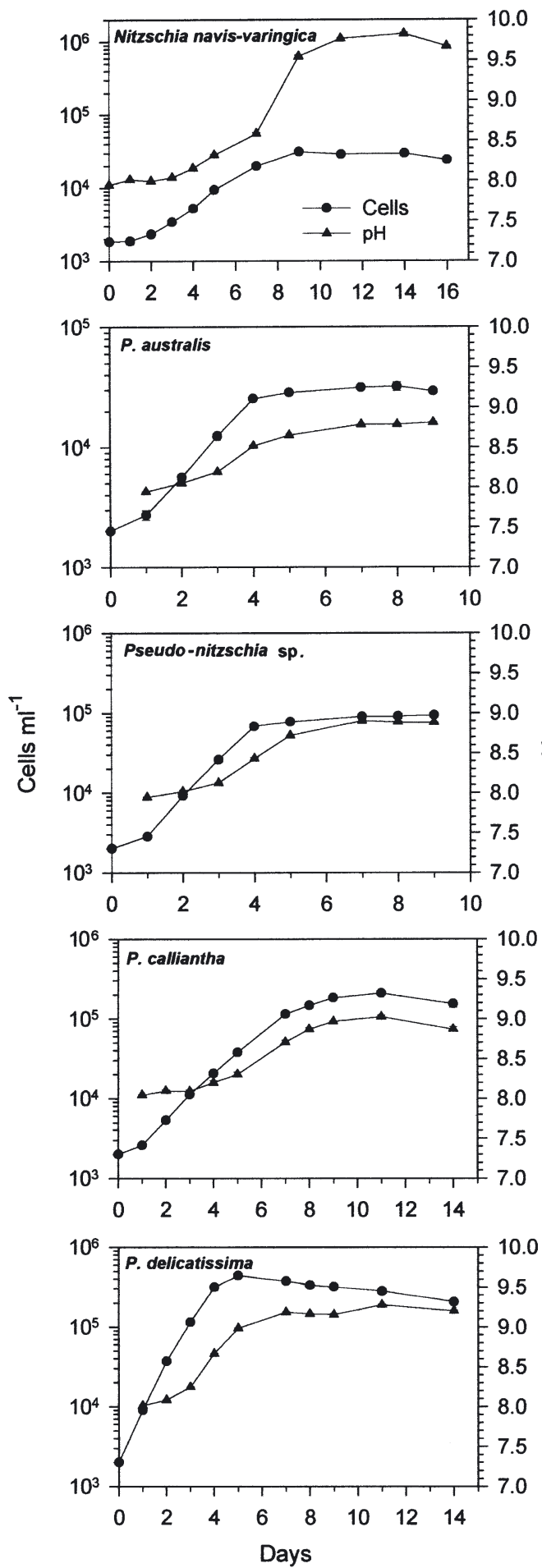

growth rate became reduced at lower pHs. Maximum growth rates were retained at pHs below 8.6 (Fig. 3). These results show that the $\mathrm{pH}$ in nutrientenriched coastal waters may potentially affect growth
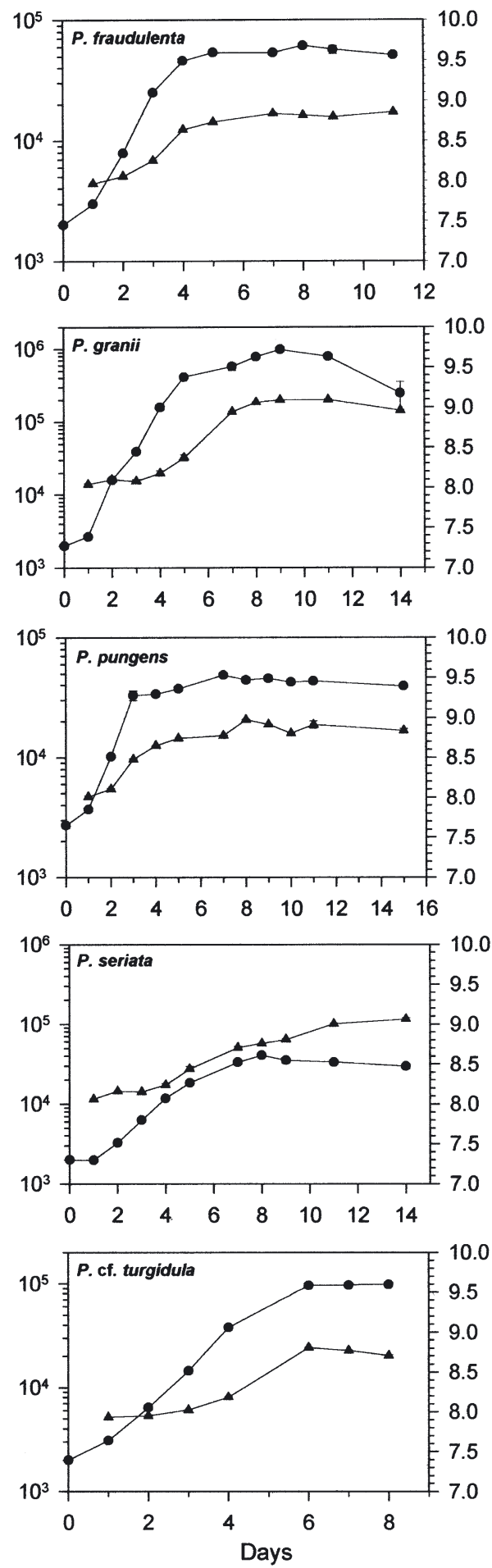

Fig. 4. Nitzschia navis-varingica, Pseudo-nitzschia australis, Pseudo-nitzschia sp., P. calliantha, P. delicatissima, P. fraudulenta, P. granii, P. pungens, P. seriata, P. cf. turgidula. Growth and $\mathrm{pH}$ changes as a function of time in batch-culture experiments. Data points are means $\pm \mathrm{SE}, \mathrm{n}=3$ (where $\mathrm{SE}$ bars are not visible, $\mathrm{SE}$ values were smaller than symbols) 


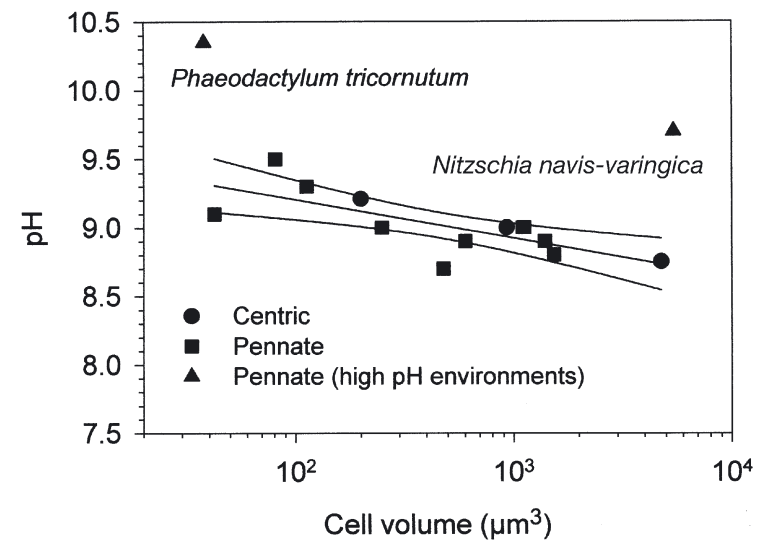

Fig. 5. $\mathrm{pH}$ as a function of cell volume of diatoms based on results from present study (Table 2) and data from other studies (Table 4) shown as a linear regression with 95\% CI

of $P$. multiseries in the field and that not only nutrient depletion but also high $\mathrm{pH}$ may be the reason that a bloom does not increase further. P. pungens, which often co-occurs in nature with $P$. multiseries, had the same $\mathrm{pH}$ limit for growth as $P$. multiseries (Table 2).

\section{Possible mechanisms responsible for effect of high pH on growth of marine microalgae}

Several explanations of how $\mathrm{pH}$ in general might influence growth have been suggested, but the physiological mechanisms are still not fully understood. High $\mathrm{pH}$ may result in carbon limitation of species that do not utilise $\mathrm{HCO}_{3}{ }^{-}$effectively. The changes in the speciation of inorganic carbon as $\mathrm{CO}_{2}, \mathrm{HCO}_{3}{ }^{-}$or $\mathrm{CO}_{3}{ }^{-}$ that follow changes in $\mathrm{pH}$ may therefore affect the growth of the algae. At $\mathrm{pH} 8.0$, about $1 \%$ of the dissolved organic carbon (DIC) is present as $\mathrm{CO}_{2}$, whereas at a $\mathrm{pH}$ value of 9.0 only about $0.1 \%$ of DIC is available as $\mathrm{CO}_{2}$ (Hinga 2002). This lower availability of $\mathrm{CO}_{2}$ may potentially reduce photosynthesis and hence growth. Many diatoms have, however, been found to utilise $\mathrm{HCO}_{3}{ }^{-}$; either by taking up $\mathrm{HCO}_{3}{ }^{-}$ actively and converting it to intracellular $\mathrm{CO}_{2}$ using carbonic anhydrase, or transforming it to $\mathrm{CO}_{2}$ using extracellular carbonic anhydrase and then utilising it for carbon fixation (e.g. Korb et al. 1997, Tortell et al. 1997). Some diatoms have even been found to be able to utilise $\mathrm{HCO}_{3}{ }^{-}$directly for carbon fixation through $\mathrm{C}_{4}$-photosynthesis (Tortell et al. 1997, Reinfelder et al. 2000).

Another reason for the effect of elevated $\mathrm{pH}$ on phytoplankton is that $\mathrm{pH}$ may affect the bioavailability and/or toxicity of metals to marine microalgae (Sunda \& Guillard 1976, Gensemer et al. 1993, Granéli \& Har- aldsson 1993, Craig et al. 2003). Conclusions on the effect of $\mathrm{pH}$ on metals and their toxicity, however, usually cannot be firmly established, since several studies have recorded opposite results (Peterson et al. 1984). For example, despite constant concentrations of copper ion, an increase in $\mathrm{pH}$ from 7.7 to 8.7 decreased copper toxicity in the diatom Thalassiosira pseudonana, possibly due to increased chelation of copper ions (Sunda \& Guillard 1976). However, another study found no changes in copper toxicity for Pyrocystis lunula in the 8 to $10 \mathrm{pH}$ interval and a decrease in $\mathrm{pH}$ to below 6 even counteracted copper toxicity (Craig et al. 2003). This clearly illustrates that final conclusions with respect to the effect of $\mathrm{pH}$ changes on the toxicity or availability of a metal are often difficult to make. In addition, there is evidence that the effect of $\mathrm{pH}$ on metal toxicity depends on the metal species itself (Wang 1987).

Apart from the 2 mechanisms suggested above, high $\mathrm{pH}$ may also influence the processes and energy involved in maintaining intracellular $\mathrm{pH}$ and cause changes to membrane transport processes (Raven 1980). Enzymatic processes in cells have different $\mathrm{pH}$ optima, and hence a shift in intracellular $\mathrm{pH}$ may affect the rate of the metabolic processes (Taraldsvik \& Myklestad 2000). The existing knowledge on the effect of $\mathrm{pH}$ on the maintenance of intracellular $\mathrm{pH}$ and transport processes across the membrane in microalgae is sparse and further studies are greatly needed.

\section{Upper pH limits for growth and their relationship with cell volume and the environment}

Examination of the data for all the potentially toxic diatoms included in this study indicates a relationship between the environment from which the algae are isolated and their $\mathrm{pH}$ limit for growth. The highest $\mathrm{pH}$ limit for growth (9.7 to 9.8) was found in Nitzschia navis-varingica isolated from a brackish $(27 \mathrm{psu})$ shrimp pond in Vietnam (Kotaki et al. 2000). In such shrimp ponds, $\mathrm{pH}$ values of up to 9.1 to 10.7 have been found (N. N. Lam pers. comm.). Of the remaining 10 Pseudo-nitzschia species, the maximum $\mathrm{pH}$ for growth was below 9.3. This may reflect the fact that all these species typically exist as planktonic life forms (Hasle 2002), e.g. none of them are benthic or found in rock pools or ponds, environments that often experience very high $\mathrm{pH}$ conditions.

Taking not only potentially toxic diatoms, but diatoms in general into consideration, is it possible to determine a relationship between environment and $\mathrm{pH}$ limitations for growth? Only a limited number of diatoms have been studied with respect to effect of $\mathrm{pH}$ on growth, and among those studied, the $\mathrm{pH}$ limits for 
growth vary (Table 4). Some diatoms such as Cerataulina pelagica and Thalassiosira punctigera cannot grow when the $\mathrm{pH}$ exceeds 8.5 to 9.0 (Elzenga et al. 2000, Pedersen \& Hansen 2003). The growth of other diatoms such as Skeletonema costatum, T. pseudonana and T. oceanica is limited at $\mathrm{pH}$ values above 8.5 or 8.8 and is inhibited when pH exceeds 9.4 (Chen \& Durbin 1994, Taraldsvik \& Myklestad 2000, Schmidt \& Hansen 2001). The diatom species with the highest $\mathrm{pH}$ limit for growth is Phaeodactylum tricornutum, which is able to grow even when the pH exceeds 10 (Humphrey 1975, Goldman et al. 1982, Nimer et al. 1997). This species is mainly found in intertidal rock pools (Hasle \& Syvertsen 1997), and $\mathrm{pH}$ values up to 9.3 have been found in such rock pools (see Knopp et al. 2003, www.hut.fi/ rjmatti2/projektit/Tvar2003_kirppu.pdf). Thus, diatoms like Nitzschia navis-varingica and P. tricornutum that grow in environments such as marine ponds and rock pools appear to have higher pH limits (Fig. 5). Both environments are characterised by periods of very high $\mathrm{pH}$. It seems therefore likely that these organisms have evolved a way to exist in such environments through a yet unknown mechanism.

We found a significant semi-logarithmic relationship between the upper $\mathrm{pH}$ limit for growth and cell volume for diatoms with a planktonic lifestyle (Fig. 5). This relationship, which is valid for both centric and pennate diatoms, shows that smaller diatoms have a higher upper $\mathrm{pH}$ limit for growth than larger diatoms. The mechanism most probably responsible for the observed relationship is the regulation and maintenance of intracellular $\mathrm{pH}$. The larger surface/volume of smaller cells size may allow them to better regulate their intracellular $\mathrm{pH}$, because the maintenance of intracelular $\mathrm{pH}$ is presumed to be controlled by surface-associated ion-exchange processes (e.g. Gatti \& Christen 1985, Boron 1986, Biagini et al. 2001). At high pH levels, smaller cells thus have a relatively larger surface area and hence a larger potential for maintaining a stable intracellular $\mathrm{pH}$.

\section{Effect of high pH on DA production}

In 2 strains of Pseudo-nitzschia multiseries, elevated $\mathrm{pH}$ resulted in limitation of growth. Simultaneously to the increase in $\mathrm{pH}$, DA was detected (Fig. 1). Domoic acid production began during late exponential growth phase (Fig. 1D,H) and was only found in the cells during this phase (Fig. 1B,F). During late exponential phase, $\mathrm{pH}$ increased and hence elevated $\mathrm{pH}$ is a possible explanation for the induction of production of DA. Neither nutrients nor vitamins were limiting. Salinity, temperature and light were unchanged and bacteria were present during the whole experiment although they were not enumerated. The variable parameter was $\mathrm{pH}$ and an increased $\mathrm{pH}$ in the late exponential phase was followed by an increase in production of DA. Thus, we suggest that elevated $\mathrm{pH}$ accounts for the production of DA. Similarly, studies on Oscillatoria laetevirens and Chrysochromulina polylepis found that increasing $\mathrm{pH}$ from 7 to 10 led to increased toxin concentration or increased toxicity of exudates, respectively (Ray \& Bagchi 2001, Schmidt \& Hansen 2001).

Table 4. Upper pH limits for growth of diatoms. Data from studies in which growth was not considered as being nutrient-limited. nd means no data. Cell volumes based on measurements of Hasle \& Syvertsen (1997), Schmidt \& Hansen (2001) and Pedersen \& Hansen (2003) and M. F. Pedersen (pers. comm.)

\begin{tabular}{|c|c|c|c|}
\hline Species & pH limit & Cell vol. $\left(\mu \mathrm{m}^{3}\right)$ & Source \\
\hline Phaeodactylum tricornutum & $>10,10.4,10.3$ & 38 & Humphrey (1975), Goldman et al. (1982), Nimer et al. (1997) \\
\hline $\begin{array}{l}\text { Asterionellopsis glacialis } \\
\text { (as Asterionella japonica) }\end{array}$ & ca. $9 \cdot 2^{\mathrm{a}}$ & nd & Kain \& Fogg (1958) \\
\hline Cerataulina pelagica & $8.5-9.0$ & 4762 & Pedersen \& Hansen (2003) \\
\hline Chaetoceros didymus & 9.2 & nd & Humphrey (1975) \\
\hline Cylindrotheca closterium & $>9.5,8.5^{\mathrm{b}}, 9.5^{\mathrm{b}}$ & 81 & Humphrey (1975), Pedersen \& Hansen (2003) \\
\hline Leptocylindrus minimus & 9.0 & 932 & Pedersen \& Hansen (2003) \\
\hline Nitzschia sp. & 9.5 & nd & Humphrey (1975) \\
\hline $\begin{array}{l}\text { Odontella aurita } \\
\text { (as Biddulphia aurita) }\end{array}$ & 9.2 & nd & Humphrey (1975) \\
\hline Skeletonema costatum & 9.21, са. 9.5 & 200 & Schmidt \& Hansen (2001) \\
\hline Thalassiosira oceanica & $9.4-9.5$ & nd & Chen \& Durbin (1994) \\
\hline Thalassiosira pseudonana & $9.4-9.5,9.77$ & nd & Chen \& Durbin (1994), Elzenga et al. (2000) \\
\hline Thalassiosira punctigera & 8.9 & nd & Elzenga et al. (2000) \\
\hline
\end{tabular}


Small amounts of DA were detected in the mid- to late-exponential growth phase (Fig. 1). DA has previously been detected in this phase in Pseudo-nitzschia multiseries, P. australis, P. seriata and P. pungens (e.g. Garrison et al. 1992, Lundholm et al. 1994, Pan et al. 1996b, 2001, Trainer et al. 1998). This growth phase has been explained either as (1) a transition stage between exponential and stationary growth during which some cells stop growth while others just slow division, or (2) as a general decrease in growth rate. In both instances, nutrient limitation or some other factor has been considered responsible (see Bates 1998). The production and concentration of DA in both medium and cells in the present study reached levels similar to those recorded in previous laboratory experiments (Bates et al. 1991, Bates 1998).

Scenarios where nutrients were not limiting but production of DA did occur have been described previously (see Bates et al. 1993, Pan et al. 1996c). A possible explanation for these scenarios could be elevated $\mathrm{pH}$. We suggest that production of DA is influenced by several factors, including $\mathrm{pH}$ and depletion of silicate and phosphate, and that elevation of $\mathrm{pH}$ may interact in different ways in different scenarios. Pan et al. (1996b, c) suggested the existence of 2 phases (I and II) in the production of DA. Phase II corresponded to the typical nutrient stress situations in which growth was evidently limited by depletion of nutrients and production of DA was therefore enhanced; e.g. the chemostat experiments of Pan et al. (1996c). Phase I was in batchculture experiments ascribed to the mid- to late-exponential growth phase in which nutrients were not yet evidently limiting growth. In a continuous culture experiment (Pan et al. 1996c), Phase I was described as a situation in which growth was reduced and production of DA occurred under conditions where neither silicate nor any of the other nutrients, vitamins or light were limiting. The population size stayed at a certain level and low amounts of DA were produced. This was explained as being due to an 'intrinsic physiological mechanism' (Pan et al. 1996c). We suggest that a potential explanation for the production of DA under the conditions where nutrients were not limiting could be the effect of elevated $\mathrm{pH}$. (It should be mentioned that in Pan et al.'s [1996c] study the production of DA was higher in the continuous cultures limited by silicate than in the cultures limited by the intrinsic mechanism, possibly pH.) Further studies examining the combined effects of elevated $\mathrm{pH}$ and nutrient levels are under way by the authors.

In Pseudo-nitzschia pungens, no production of DA was detected (detection limit $0.3 \mathrm{ng} \mathrm{m}^{-1}$ ) at elevated $\mathrm{pH}$. This is not surprising, as both toxic and non-toxic clones of $P$. pungens from geographically diverse locations have been found (e.g. Bates et al. 1993, MacKen- zie et al. 1993, Villac et al. 1993, Lundholm et al. 1994, Rhodes et al. 1996, Trainer et al. 1998). This scenario, with the existence of both toxic and non-toxic strains of the same species, is also known for other Pseudonitzschia species. Both toxic and non-toxic strains of (e.g.) P. australis (Villac et al. 1993), P. calliantha (Lundholm et al. 2003), P. multiseries (e.g. Bates et al. 1989, Villareal et al. 1994), and P. seriata (Bates et al. 1989, Lundholm et al. 1994) have been found. These differences among strains could be a question of detection limit, or could be due to intraspecific genetic differences among strains or to differences in the factors controlling the production of DA. An experiment with one $P$. pungens strain therefore does not exclude the possibility that other strains of the same species might produce DA under conditions in which elevated $\mathrm{pH}$ is the inducing factor.

\section{Possible mechanisms of DA production}

It has generally been concluded that physiological stress caused by silicate and phosphate limitation enhances DA production (Bates 1998, Pan et al. 1998). Physiological stress arising through temperature or light conditions, however, does not enhance DA production (Bates et al. 1991, Bates \& Leger 1992, Lewis et al. 1993, Lundholm et al. 1994). This indicates that different mechanisms may be responsible for the production of DA. Silicate has been hypothesized to promote production of DA indirectly by arresting cells in the cell cycle at 'a particular phase that is conducive to DA production' (Pan et al. 1998). On the other hand, phosphate limitation leading to decreased use of precursors such as acetyl CoA for lipid synthesis has resulted in an increased availability of these precursors for the production of DA (Pan et al. 1996a).

One of the possible explanations for a mechanism mediating the effect of $\mathrm{pH}$ on the DA production could be that enzymatic processes involved in production of DA have a certain $\mathrm{pH}$ optimum, and hence a shift in intracellular $\mathrm{pH}$ may affect the production of DA. In fact, it was shown by Taraldsvik \& Myklestad (2000) that the composition of the cellular content of 19 different amino acids changed due to elevated extracellular $\mathrm{pH}$. The concentration of some of the amino acids was constant over a broad $\mathrm{pH}$ interval, whereas the concentrations of others varied as a function of $\mathrm{pH}$.

Another explanation for the effect of $\mathrm{pH}$ on DA production could be carbon limitation at high pHs. However, if carbon were depleted, one would expect a decrease, not an increase, in production of DA, as carbon is needed for the synthesis of the toxin. In addition, we do not consider this mechanism very likely, as most diatoms have been found to be able to 
utilise $\mathrm{HCO}_{3}{ }^{-}$as carbon source in one way or another (e.g. Nimer et al. 1997, Tortell et al. 1997, Hobson et al. 2001).

A third potential explanation for the effect of $\mathrm{pH}$ on DA production could be that $\mathrm{pH}$ - mediated changes in speciation of metals affect the production of DA due to increased toxicity or reduced bioavailability of the metal. No study has examined the possibility 'elevated $\mathrm{pH} \rightarrow$ increased metal toxicity $\rightarrow$ induction of DA production'. It is therefore necessary to combine the results of various studies examining individual processes. Studies on the effects of $\mathrm{pH}$ on metal toxicity are, as mentioned, conflicting. A study on copper toxicity to a diatom showed that increased $\mathrm{pH}$ resulted in reduced, not increased, toxicity of copper (Sunda \& Guillard 1976). Studies on the induction of DA by metals have shown that copper toxicity (and iron limitation) induce production of DA (e.g. Maldonado et al. (2002). Maldonado et al. (2002) also found that copper toxicity (and iron limitation) in the exponential growth phase induced active transport of DA to the medium. Such active transport of DA was not seen in the present study; on the contrary, DA was only found in cells in the exponential phase. This indicates that copper toxicity (and iron limitation) is probably not the explanation for the $\mathrm{pH}$-mediated induction of DA. On the other hand, studies on diatoms at higher $\mathrm{pH}$ levels are lacking, and in general studies on pH-related toxicity of copper on living organisms are contradictory (Craig et al. 2003). Therefore, we cannot reject the possibility that $\mathrm{pH}$-mediated changes in the speciation of other metals could explain the production of DA at elevated $\mathrm{pHs}$, since $\mathrm{pH}$ is known to affect the bioavailability and toxicity of metals such as Zn, Mn and Al (Gensemer et al. 1993).

A fourth possibility is that bacterial composition could change following changes in the $\mathrm{pH}$. This hypothesis also cannot be rejected, but we find it unlikely as the only explanation, since even axenic cultures have been found to produce DA (Bates 1998).

\section{pH and natural occurrences of Pseudo-nitzschia spp. and DA}

In general, measurements of $\mathrm{pH}$ during algal blooms have shown that in open coastal areas, blooms of microalgae may result in $\mathrm{pH}$ values of up to 8.7 (e.g. Pegler \& Kempe 1988, Brussard et al. 1996, Hinga 2002). In semi-enclosed coastal areas such as fjords and lagoons, pH may attain even higher values, up to around 10 during blooms (e.g. Marshall \& Orr 1948, Macedo et al. 2001, Hansen 2002).

We have not been able to find any field data connecting $\mathrm{pH}$ with the occurrence of Pseudo-nitzschia or
DA. However, Pseudo-nitzschia species are often found in large densities in coastal areas and often in areas that receive nutrient input from either upwelling or freshwater run-off (e.g. Yuzao et al. 1996, Dortch et al. 1997, Scholin et al. 2000, Trainer et al. 2000, Odebrecht et al. 2001, Stonik et al. 2001, Villac \& Tenenbaum 2001). Pseudo-nitzschia spp. may form dense blooms $\left(10^{6}\right.$ to $10^{8}$ cells $\left.\mathrm{l}^{-1}\right)$, during which they account for up to $99 \%$ of the total microalgal biomass (e.g. Subba Rao et al. 1988, Martin et al. 1990, Walz et al. 1994, Dortch et al. 1997, Fryxell et al. 1997, Gallacher et al. 2001, Stonik et al. 2001). Such dense blooms of Pseudo-nitzschia spp. in nutrient-enriched areas are expected to increase the $\mathrm{pH}$ to levels that could limit growth and also enhance production of DA. The most probable scenario is that an interaction of several different factors determines the production of DA in the field.

\section{Conclusions}

In batch-culture experiments, $\mathrm{pH}$ values above 8.6 reduced growth rates of Pseudo-nitzschia multiseries and $\mathrm{pH}$ levels of 8.8 to 9.0 inhibited growth. In addition, elevated $\mathrm{pH}$ levels induced production of DA in $P$. multiseries. These $\mathrm{pH}$ values are within levels previously observed during blooms of microalgae in coastal areas. Thus, inhibition of growth and induction of DA production due to elevated $\mathrm{pH}$ may potentially occur in blooms of Pseudo-nitzschia spp. in the field. Using a combination of results of the present study and data from the literature, a relationship between cell volume and the upper $\mathrm{pH}$ limits for growth was found for these diatoms, indicating that smaller cells have higher $\mathrm{pH}$ limits for growth. A possible explanation for this relationship could be related to the regulation of intracellular $\mathrm{pH}$.

Acknowledgements. We wish to thank P. M. Jönsson and E. Granéli for nutrient analyses, A. Bisgaard for help in the laboratory, N. N. Lam for access to unpublished data on $\mathrm{pH}$ in shrimp cultures, A. Marchetti, R. E. Sabaawii, S. Bates, S. Fraga and B. Bill for providing cultures and M. F. Pedersen for access to cell measurements. The work was funded by a grant to N.L. from the Carlsberg Foundation (grant 0656/20) and a grant to P.J.H. from the Natural Research Council (grant 2103-0449).

\section{LITERATURE CITED}

Abrantes F, Moita MT (1999) Water column and recent sediment data on diatoms and coccolithophorids, off Portugal, confirm sediment record of upwelling events. Oceanol Acta 22:319-336

Bargu S, Powell CL, Coale SL, Busman M, Doucette GJ, Silver MW (2002) Krill: a potential vector for domoic acid in 
marine food webs. Mar Ecol Prog Ser 237:209-216

Bates SS (1998) Ecophysiology and metabolism of ASP toxin production. In: Anderson DM, Cembella AD, Hallegraeff GM (eds.) Physiological ecology of harmful algal blooms. Springer-Verlag, Heidelberg, p 405-426

Bates SS (2000) Domoic-acid-producing diatoms: another genus added! J Phycol 36:978-983

Bates SS, Léger C (1992) Response of Nitzschia pungens f. multiseries to irradiance: growth and domoic acid production. Can Tech Rep Fish Aquat Sci 1893:9-10

Bates SS, Bird CJ, de Freitas ASW, Foxall R and 13 others (1989) Pennate diatom Nitzschia pungens as the primary source of domoic acid, a toxin in shellfish from eastern Prince Edward Island, Canada. Can J Fish Aquat Sci 46:1203-1215

Bates SS, de Freitas ASW, Milley JE, Pocklington R, Quilliam MA, Smith JC, Worms J (1991) Controls on domoic acid production by the diatom Nitzschia pungens f. multiseries in culture: nutrients and irradiance. Can J Fish Aquat Sci 48:1136-1144

Bates SS, Worms J, Smith JC (1993) Effects of ammonium and nitrate on domoic acid production by Nitzschia pungens in batch culture. Can J Fish Aquat Sci 50:1248-1254

Biagini GA, Knodler LA, Saliba KJ, Kirk K, Edwards MR (2001) $\mathrm{Na}^{+}$-dependent $\mathrm{pH}$ regulation by the amitochondriate protozoan parasite Giardia intestinalis. J Biol Chem 276:29157-29162

Boron WF (1986) Intracellular $\mathrm{pH}$ regulation in epithelial cells. Annu Rev Physiol 48:377-388

Brussaard CPD, Gast GJ, van Duyl FC, Riegman R (1996) Impact of phytoplankton bloom magnitude on a pelagic microbial food web. Mar Ecol Prog Ser 144:211-221

Chen CY, Durbin EG (1994) Effects of pH on the growth and carbon uptake of marine phytoplankton. Mar Ecol Prog Ser 109:83-94

Craig JM, Klerks PL, Heimann K, Waits JL (2003) Effects of salinity, $\mathrm{pH}$ and temperature on the re-establishment of bioluminescence and copper or SDS toxicity in the marine dinoflagellate Pyrocystis lunula using bioluminescence as an endpoint. Environ Pollut 125:267-275

Dortch Q, Robichaux R, Pool S, Milsted D and 6 others (1997) Abundance and vertical flux of Pseudo-nitzschia in the northern Gulf of Mexico. Mar Ecol Prog Ser 146:249-264

Douglas DJ, Bates SS, Bourque LA, Selvin RC (1993) Domoic acid production by axenic and non-axenic cultures of the pennate diatom Nitzschia pungens f. multiseries. In: Smayda TJ, Shimizu Y (eds) Toxic phytoplankton blooms in the sea. Elsevier, Amsterdam, p 595-600

Elzenga JTM, Prins HBA, Stefels J (2000) The role of extracellular carbonic anhydrase activity in inorganic carbon utilization of Phaeocystis globosa (Prymnesiophyceae): a comparison with other algae using the isotopic disequilibrium technique. Limnol Oceanogr 45:372-380

Fryxell GA, Villac MC, Shapiro LP (1997) The occurrence of the toxic diatom genus Pseudo-nitzschia (Bacillariophyceae) on the west coast of the USA, 1920-1996: a review. Phycologia 36:419-437

Gallacher S, Howard G, Hess P, MacDonald E and 6 others (2001) The occurrence of amnesic shellfish poisons in shellfish from Scottish waters. In: Hallegraeff GM, Blackburn SI, Bolch CJ, Lewis RJ (eds) Harmful algal blooms 2000. Intergovernmental Oceanographic Commission of UNESCO, Paris, p 30-33

Garrison DL, Conrad SM, Eilers PP, Waldron EM (1992) Confirmation of domoic acid production by Pseudonitzschia australis (Bacillariophyceae) cultures. J Phycol 28:604-607

Gatti JL, Christen R (1985) regulation of internal pH of sea urchin sperm. J Biol Chem 260:7599-7602
Gensemer RW, Smith REH, Duthie HC, Schiff SL (1993) pH tolerance and metal toxicity in populations of the planktonic diatom Asterionella: influences of synthetic and natural dissolved organic carbon. Can J Fish Aquat Sci 50:121-132

Goldman JC, Azov Y, Riley CB, Dennett, MR (1982) The effect of $\mathrm{pH}$ in intensive microalgal cultures. I. Biomass regulation. J Exp Mar Biol Ecol 57:1-13

Granéli E, Haraldsson C (1993) Can increased leaching of trace metals from acidified areas influence phytoplankton growth in coastal areas? Ambio 22:308-311

Guillard RRL, Hargraves PE (1993) Stichochrysis immobilis is a diatom, not a chrysophyte. Phycologia 32:234-236

Gulland FM, Haulena M, Fauquier D, Langlois G, Lander ME, Zabka T, Duerr R (2002) Domoic acid toxicity in Californian sea lions (Zalophus californianus): clinical signs, treatment and survival. Vet Rec 150:475-80

Hansen PJ (2002) Effect of high pH on the growth and survival of marine phytoplankton: implications for species succession. Aquat Microb Ecol 28:279-288

Hasle GR (1965) Nitzschia and Fragilariopsis species studied in the light and electron microscopes. II. The group Pseudonitzschia. Skr Nor Vidensk-Akad Oslo I MatNaturvidensk KL 18:1-45

Hasle GR (2002) Are most of the domoic acid producing species of the diatom genus Pseudo-nitzschia cosmopolites? Harmful Algae 1:137-146

Hasle GR, Syvertsen EE (1997) Marine diatoms. In: Tomas CR (ed) Identifying marine phytoplankton. Academic Press, San Diego, p 5-385

Hillebrand H, Dürselen CD, Kirschtel D, Pollingher U, Zohary $\mathrm{T}$ (1999) Biovolume calculation for pelagic and benthic microalgae. J Phycol 35:403-424

Hinga KR (1992) Co-occurrence of dinoflagellate blooms and high $\mathrm{pH}$ in marine enclosures. Mar Ecol Prog Ser 86: 181-187

Hinga KR (2002) Effects of pH on coastal marine phytoplankton. Mar Ecol Prog Ser 238:281-300

Hobson, LA, Hanson, CE, Holeton C (2001) An ecological basis for extracellular anhydrase in marine unicellular algae. J Phycol 37:717-723

Horner RA, Postel JR (1993) Toxic diatoms in western Washington waters (US west coast). Hydrobiologia 269/270: 197-205

Humphrey GF (1975) The photosynthesis:respiration ratio of some unicellular marine algae. J Exp Biol Ecol 18:111-119

Kaczmarska I, Fryxell GA, Watkins TP (1986) Effect of two Gulf Stream warm-core rings on distributional patterns of the diatom genus Nitzschia. Deep-Sea Res 33:1843-1868

Kain JM, Fogg GE (1958) Studies on the growth of marine phytoplankton. J Mar Biol Assoc UK 37:397-413

Korb RE, Saville PJ, Johnston AM, Raven JA (1997) Sources of inorganic carbon for photosynthesis by three species of marine diatom. J Phycol 33:433-440

Kotaki Y, Koike K, Yoshida M, Thuoc CV, Huyen NTM, Hoi NC, Fukuyo Y, Kodama M (2000) Domoic acid production in Nitzschia sp. (Bacillariophyceae) isolated from a shrimp-culture pond in Do Son, Vietnam. J Phycol 36: $1057-1060$

Lewis NI, Bates SS, McLachlan JL, Smith JC (1993) Temperature effects on growth, domoic acid production and morphology of the diatom Nitzschia pungens f. multiseries. In: Smayda TJ, Shimizu Y (eds) Toxic phytoplankton blooms in the sea. Elsevier, Amsterdam, p 601-606

Lundholm N, Skov J, Pocklington R, Moestrup Ø (1994) Domoic acid, the toxic amino acid responsible for amnesic shellfish poisoning, now in Pseudonitzschia seriata (Bacillariophyceae) in Europe. Phycologia 33:475-478 
Lundholm N, Moestrup Ø, Hasle GR, Hoef-Emden K (2003) A study of the $P$. pseudodelicatissima/cuspidata-complex (Bacillariophyceae). What is Pseudo-nitzschia pseudodelicatissima? J Phycol 39:797-813

Macedo MF, Duarte P, Mendes P, Ferreira JG (2001) Annual variation of environmental variables, phytoplankton species composition and photosynthetic parameters in a coastal lagoon. J Plankton Res 23:719-723

MacKenzie A, White DA, Sim PG, Holland AJ (1993) Domoic acid and the New Zealand Greenshell mussel (Perna canaliculus). In: Smayda TJ, Shimizu Y (eds) Toxic phytoplankton blooms in the sea. Elsevier, Amsterdam, p 607-612

Maldonado MT, Hughes MP, Rue EL (2002) The effect of Fe and $\mathrm{Cu}$ on growth and domoic acid production by Pseudonitzschia multiseries and Pseudo-nitzschia australis. Limnol Oceanogr 47:515-526

Marshall SM, Orr AP (1948) Further experiments on the fertilization of a sea loch (Loch Craiglin). The effect of different plant nutrients on the phytoplankton. J Mar Biol Assoc UK 27:360-379

Martin JL, Haya K, Burridge LE, Wildish DJ (1990) Nitzschia pseudodelicatissima - a source of domoic acid in the Bay of Fundy, eastern Canada. Mar Ecol Prog Ser 67:177-182

McGinness, KL, Fryxell GA, McEachran JD (1995) Pseudonitzschia species found in digestive tracts of northern anchovies (Engraulis mordax). Can J Zool 73:642-647

Nimer NA, Iglesias-Rodriguez MD, Merrett MJ (1997) Bicarbonate utilization by marine phytoplankton species. J Phycol 33:625-631

Odebrecht C, Ferrario ME, Ciotti AM, Kitzmann D, Odete M, Moreira P, Hinz F (2001) The distribution of the diatom Pseudo-nitzschia off southern Brazil and relationships with oceanographic conditions. In: Hallegraeff GM, Blackburn SI, Bolch CJ, Lewis RJ (eds) Harmful algal blooms 2000. Intergovernmental Oceanographic Commission of UNESCO, Paris, p 42-45

Pan Y, Subba Rao DV, Mann KH (1996a) Changes in domoic acid production and cellular chemical composition of the toxigenic diatom Pseudo-nitzschia multiseries under phosphate limitation. J Phycol 32:371-381

Pan Y, Subba Rao DV, Mann KH, Brown RG, Pocklington R (1996b) Effects of silicate limitation on production of domoic acid, a neurotoxin, by the diatom Pseudo-nitzschia multiseries. I. Batch culture studies. Mar Ecol Prog Ser 131:225-233

Pan Y, Subba Rao DV, Mann KH, Li WKW, Harrison WG (1996c) Effects of silicate limitation on production of domoic acid, a neurotoxin, by the diatom Pseudo-nitzschia multiseries. II. Continuous culture studies. Mar Ecol Prog Ser 131:235-243

Pan Y, Bates SS, Cembella AD (1998) Environmental stress and domoic acid production by Pseudo-nitzschia: a physiological perspective. Nat Toxins 6:127-135

Pan Y, Parsons ML, Busman M, Moeller PDR, Dortch Q, Powell CL, Doucette GJ (2001) Pseudo-nitzschia sp. cf. pseudodelicatissima - a confirmed producer of domoic acid from the northern Gulf of Mexico. Mar Ecol Prog Ser 220:83-92

Parsons ML, Dortch Q, Turner RE (2002) Sedimentological evidence of an increase in Pseudo-nitzschia (Bacillariophyceae) abundance in response to coastal eutrophication. Limnol Oceanogr 47:551-558

Pedersen MF, Hansen PJ (2003) Effects of high pH on a natural marine planktonic community. Mar Ecol Prog Ser 260:19-31

Pegler K, Kempe S (1988) The carbonate system of the North Sea: determination of alkalinity and $\mathrm{TCO}_{2}$ and calculation of $\mathrm{PCO}_{2}$ and $\mathrm{SI}_{\text {cal }}$ (Spring 1986). Mitt Geol-Paläont Inst
Univ Hamburg 65:35-87

Peterson HG, Healey FP, Wagemann R (1984) Metal toxicity to algae: a highly $\mathrm{pH}$ dependent phenomenon. Can J Fish Aquat Sci 41:974-979

Pocklington R, Milley JE, Bates SS, Bird CJ, de Freitas ASW, Quilliam MA (1990) Trace determination of domoic acid in seawater and phytoplankton by high-performance liquid chromatography of the fluorenylmethoxycarbonyl (FMOC) derivative. Intern $\mathrm{J}$ Environ Anal Chem 38: 351-368

Raven JA (1980) Nutrient transport in microalgae. Adv Microb Physiol 21:47-226

Ray S, Bagchi SN (2001) Nutrients and pH regulate algicide accumulation in cultures of the cyanobacterium Oscillatoria laetevirens. New Phytol 149:455-460

Reinfelder JR, Kraepiel AML, Morel FMM (2000) Unicellular $\mathrm{C}_{4}$ photosynthesis in a marine diatom. Nature 407: 996-999

Rhodes L, White D, Syhre M, Atkinson M (1996) Pseudonitzschia species isolated from New Zealand coastal waters: domoic acid production in vitro and links with shellfish toxicity. In: Yasumoto, T, Oshima Y, Fukuyo Y (eds) Harmful and toxic algal blooms. Intergovernmental Oceanographic Commission of UNESCO, Paris, p 155-158

Schmidt LE, Hansen PJ (2001) Allelopathy in the prymnesiophyte Chrysochromulina polylepis: effect of cell concentration, growth phase and pH. Mar Ecol Prog Ser 216: $67-81$

Scholin CA, Gulland F, Doucette GJ, Benson S and 22 others (2000) Mortality of sea lions along the central California coast linked to a toxic diatom bloom. Nature 403:80-84

Smith JC, Cormier R, Worms J, Bird CJ, Quilliam MA, Pocklington R, Angus R, Hanic L (1990) Toxic blooms of the domoic acid containing diatom Nitzschia pungens in the Cardigan River, Prince Edward Island. In: Granéli E, Sundström B, Edler L, Anderson DM (eds) Toxic marine phytoplankton. Elsevier, New York, p 227-232

Smith JC, McLachlan JL, Cormier PG, Pauley KE, Bouchard N (1993) Growth and domoic acid production and retention by Nitzschia pungens forma multiseries at low temperatures. In: Smayda TJ, Shimizu Y (eds) Toxic phytoplankton blooms in the sea. Elsevier, Amsterdam, p 631-636

Stonik IV, Orlova TY, Shevchenko OG (2001) Morphology and ecology of the species of the genus Pseudo-nitzschia (Bacillariophyta) from Peter the Great Bay, Sea of Japan. Russ J Mar Biol 27:362-366

Subba Rao DV, Quilliam MA, Pocklington R (1988) Domoic acid-a neurotoxic amino acid produced by the marine diatom Nitzschia pungens in culture. Can J Fish Aquat Sci 45:2076-2079

Sunda W, Guillard RRL (1976) The relationship between cupric ion activity and the toxicity of copper to phytoplankton. J Mar Res 34:511-529

Taraldsvik M, Myklestad SM (2000) The effect of pH on growth rate, biochemical composition and extracellular carbohydrate production of the marine diatom Skeletonema costatum. Eur J Phycol 35:189-194

Tortell PD, Reinfelder JR, Morel FMM (1997) Active uptake of bicarbonate by diatoms. Nature 390:243-244

Trainer VL, Wekell JC, Horner R, Hatfield CL, Stein JE (1998) Domoic acid producing Pseudo-nitzschia pungens. In: Reguera B, Blanco J, Fernández ML, Wyatt T (eds) Harmful algae. Xunta de Galicia and Intergovernmental Oceanographic Commission of UNESCO, Paris, p 337-339

Trainer VL, Adams NG, Bill BD, Stehr CM, Wekell JC (2000) Domoic acid production near Californian coastal upwelling zones, June 1998. Limnol Oceanogr 45:1818-1833 
Utermöhl H (1958) Zur Vervollkommnung der quantitativen Phytoplanktonmethodik. Mitt Int Ver Theor Angew Limnol 9:1-38 (in German with English Abstract)

Valderrama JC (1995) Methods of nutrient analysis. In: Hallegraeff GM, Anderson DM, Cembella AD (eds) Manual of harmful marine microalgae, IOC manuals and guides, No. 33. UNESCO, Paris, p 251-268

Villac MC, Tenenbaum DR (2001) The coastal Pseudonitzschia from the state of Rio de Janeiro, Brazil. In: Hallegraeff GM, Blackburn SI, Bolch CJ, Lewis RJ (eds) Harmful algal blooms 2000. Intergovernmental Oceanographic Commission of UNESCO, Paris, p 34-37

Villac MC, Roelke DL, Chavez FP, Cifuentes LA, Fryxell GA (1993) Pseudonitzschia australis and related species from the west coast of the USA: occurrence and domoic acid production. J Shellfish Res 12:457-465

Villareal TA, Roelke DL, Fryxell GA (1994) Occurrence of the toxic diatom Nitzschia pungens f. multiseries in Massachusetts Bay, Massachusetts, USA Mar Environ Res 37:417-423

Editorial responsibility: Otto Kinne (Editor),

Oldendorf/Luhe, Germany
Walz PM, Garrison DL, Graham WM, Cattey MA, Tjeerdema RS, Silver MW (1994) Domoic acid-producing diatom blooms in Monterey Bay, California: 1991-1993. Nat Toxins 2:271-279

Wang W (1987) Factor affecting metal toxicity to (and accumulation by) aquatic organisms - overview. Environ Int 13:437-457

Work TM, Beale AM, Fritz L, Quilliam MA, Silver M, Buck K, Wright JLC (1993) Domoic acid intoxication of brown pelicans and cormorants in Santa Cruz, California. In: Smayda TJ, Shimizu Y (eds) Toxic phytoplankton blooms in the sea. Elsevier, Amsterdam, p 643-650

Yuzao Q, Ju W, Lei Z (1996) The taxonomy and bloom ecology of Pseudo-nitzschia on the coasts of China. In: Nontji A, Soemodihardjo S, Ilahude AG, Setiapermana D, Praseno DP, Moosa MK, Ongkosongo OSR (eds) Proc IOCWESTPAC. Research and Development Centre for Oceanology, Indonesia Institute of Sciences, Jakarta, p 88-95

Submitted: December 1, 2003; Accepted: March 16, 2004 Proofs received from author(s): May 19, 2004 